\title{
Maintaining antioxidants in tomato fruit using chitosan and vanillin coating during ambient storage
}

\author{
${ }^{1,2,3 *}$ Safari, Z.H., ${ }^{2}$ Ding, P., ${ }^{3}$ Sabir, A.A., ${ }^{3}$ Atif, A., ${ }^{4}$ Yaqubi, A. and ${ }^{5}$ Yusoff, S.F. \\ ${ }^{1}$ Head of Research Management Center of Arakozia Institute of Higher Education Lashkar Gah, Helmand, \\ Afghanistan. \\ ${ }^{2}$ Department of Crop Science, Faculty of Agriculture, Universiti Putra Malaysia, 43400 Serdang, Selangor \\ Darul Ehsan, Malaysia. \\ ${ }^{3}$ Department of Horticulture, Faculty of Agriculture, Helmand University, 3901 Peace watt, Lashkar Gah, \\ Helmand, Afghanistan. \\ ${ }^{4}$ Department of Internal Medicine, Arakozia Teaching Hospital, 3901 Naseri square, Lashkar Gah, \\ Helmand, Afghanistan. \\ ${ }^{5}$ Department of Agricultural Science, Faculty of Technical and Vocational, Universiti Pendidikan Sultan \\ Idris, 35900, Tanjong, Malim, Perak, Malaysia.
}

\begin{abstract}
Article history:
Received: 1 February 2021

Received in revised form: 20

March 2021

Accepted: 22 May 2021

Available Online: 30 October 2021
\end{abstract}

\section{Keywords:}

Antioxidant,

Vitamin C,

Lycopene,

Total Phenolic Contents,

Antioxidant activity

DOI:

https://doi.org/10.26656/fr.2017.5(5).075

\begin{abstract}
A high intake of antioxidants in a daily diet could reduce the risk of several diseases, including certain cancers and heart disease. Tomato is one of the rich sources of antioxidant compounds. However, it has a relatively short postharvest life due to several factors such as postharvest diseases, accelerated ripening and senescence that hasten the losses in quantity and quality. Chitosan and vanillin could be an alternative to disease control, maintain the quality and prolong the shelf life of fruit. This research aimed to evaluate the potential of chitosan and vanillin coating on tomato antioxidant properties during storage at $26 \pm 2{ }^{\circ} \mathrm{C}$ and $60 \pm 5 \%$ relative humidity. Chitosan and vanillin in aqueous solutions of $0.5 \%$ chitosan $+10 \mathrm{mM}$ vanillin, $1 \%$ chitosan $+10 \mathrm{mM}$ vanillin, $1.5 \%$ chitosan $+10 \mathrm{mM}$ vanillin, $0.5 \%$ chitosan $+15 \mathrm{mM}$ vanillin $1 \%$ chitosan $+15 \mathrm{mM}$ vanillin and $1.5 \%$ chitosan $+15 \mathrm{mM}$ vanillin, respectively, were used as edible coating on tomato fruit. The analysis was evaluated at a 5-day interval. The results revealed that $1.5 \%$ chitosan $+15 \mathrm{mM}$ vanillin have significantly retained tomato's antioxidant properties and prolonged shelf life up to 25 days without any adverse effects on fruit quality. Thus, combining $1.5 \%$ chitosan and $15 \mathrm{mM}$ vanillin is highly recommended as a tomato coating to maintain their quality, particularly in the absence of a refrigeration facility during marketing.
\end{abstract}

\section{Introduction}

Tomato (Lycopersicon esculentum Mill) is among the most popular and consumed vegetables globally after potatoes (Sucharitha et al., 2018). Nutritionally, tomato is a rich source of antioxidant compounds such as vitamin $\mathrm{C}$, lycopene and total phenolic contents that support many health benefits. Intake of these exogenous antioxidants through daily diets can reduce the risk of heart disease (Liu et al., 2018), cancer (Forni et al., 2019), oxidative stress (Jing et al., 2019), and cardiovascular diseases (Mehta et al., 2018). Vitamin C is a water-soluble vitamin naturally found in fruits and vegetables is vitamin $\mathrm{C}$ and it is a powerful antioxidant and acts to prevent or reduce the damage caused by reactive oxygen species in fruit (Valente et al., 2011; Khaliq et al., 2015). Lycopene is the major carotenoid compound of tomato with bright red carotenoid pigment and phytochemical found in tomato and other red fruit (Abebe et al., 2017). In addition to natural antioxidants, oxidation of lipids or other molecules may be postponed or restrained by inhibiting the initiation of oxidative chain reactions (Ali et al., 2013). However, tomato is a climacteric fruit has short storage life due to several factors, for instance, disease incidence, high respiration, enhanced ripening. Tomato can be store about 8-12 days after harvest at ambient temperature (Mwende et al., 2018). In postharvest handling, maintaining tomato quality is very crucial. In developing countries, the 
quality loss is commonly due to inadequate post-harvest handling, poor transportation systems, fluctuated temperature, low relative humidity $(\mathrm{RH})$, unstable gaseous exchange during storage and invasion of postharvest diseases (Arah et al., 2015).

Naturally, the quality of fruit after harvest cannot be improved but it can be preserved by applying appropriate post-harvest management techniques. Recently there are many non-chemical treatments approach has been proposed as an alternative for the control of postharvest diseases prolong storage life and retain antioxidant properties (Ippolito and Sanzani, 2011). However, researchers suggested that edible coatings can be used as one of the alternative treatments in prolonging postharvest life and maintain the quality of fruit as well as keeping low production costs (Mahfoudhi et al., 2014). This technique can act as a barrier to water loss, physical, chemical, microbiological activity, antibrowning agents, and exchange of gases and lowering the oxidative reaction rate and maintain the nutritional quality during storage (Kore et al., 2017; Bal, 2019). Generally, the materials such as polysaccharides, proteins, lipids, and composites coating were primarily used as an edible coating. (Nor and Ding, 2020). Among them, chitosan is a polysaccharide that has the ability to form semi-permeable films, to retard the fruit deterioration and extend the storage life of fruit by inhibiting the growth of microorganisms and modifying the internal atmosphere to reduce respiration and ethylene production rate that delay changes in antioxidant properties (Safari et al., 2020).

Vanillin is an organic phenolic aldehyde and being a powerful antioxidant biophenol is often used as a flavouring and fragrance agent in foods, beverages, and pharmaceuticals (Vijayalakshmi et al., 2019). Besides this, it is also used as a food preserving agent, due to its antimicrobial, anti-mould, anti-yeast, and antioxidant activities (Ciriminna et al., 2019). The antimicrobial property of vanillin is due to the effect of phenolic compound in its chemical structure, which makes vanillin effective in inhibiting bacteria, yeasts and moulds by direct damage to the fungal cell membrane (Suwarat Rakchoy, 2009). Besides, vanillin has suppressant effects on invasive pathogens including yeasts, moulds, and bacteria, thus control the decay of fruit (Safari et al., 2021). Chitosan coating delayed in changes the ascorbic acid content in fruit during storage such as apricot (Ghasemnezhad et al., 2010), tomato fruit (Kumari et al., 2016) and guava (Thaipong et al., 2006). Mandal et al. (2018) reported that 2\% chitosan coating on tomato fruit caused declining in lycopene content during 22 days of storage in ambient conditions. Up to now, there is limited information on the effect of chitosan combined with vanillin as a coating treatment on antioxidants properties and activities of tomato stored at room temperature $26 \pm 2{ }^{\circ} \mathrm{C} / 60 \pm 5 \% \mathrm{RH}$. For this reason, this study was set out to determine the combined effects of chitosan and vanillin as a coating agent on antioxidant properties and activities and storage life of tomato fruit.

\section{Materials and methods}

\subsection{Fruit materials}

Pink colour tomato (10 to $30 \%$ of the surface is yellow to pink according to USDA class 3 colour) from Syngenta 1039 variety was obtained from Weng Seng Vegetable Products Sdn. Bhd., Cameron Highlands, Pahang, Malaysia. On the same day of harvesting, the tomato was transported to Postharvest Laboratory Science, Faculty of Agriculture, Universiti Putra Malaysia. The fruit was sorted in terms of uniformity, maturity, weight (ranged between 90-110 g) and free from any blemishes and damages.

\subsection{Preparation of coating solutions}

Commercial chitosan originated from shrimp-shell crustaceans with $85 \%$ deacetylation was purchased from Enviro Clean Energy Sdn. Bhd., Perintis Teknologi Pertanian, Malaysia (ECO. www.kitosan.my). Meanwhile, vanillin (99\%) was purchased from Evergreen Engineering and Resources Sdn. Bhd., 43500 Semenyih, Selangor, Malaysia. Chitosan solution at 0.5, 1 and $1.5 \% \mathrm{v} / \mathrm{v}$ were prepared and adjusted to $\mathrm{pH} 5.6$ with $1 \mathrm{M} \mathrm{NaOH}$. Tween 20 at $0.1 \%$ was supplemented to improve the solution wettability. Distilled water without chitosan containing $0.1 \%$ Tween 20 was served as control. Vanillin powder was dissolved in distilled water in concentrations of 10 and $15 \mathrm{mM}$ and heat at $83^{\circ} \mathrm{C}$ for 5 mins using a hot plate magnetic stirrer until vanillin powder was completely dissolved. Then, each vanillin solution was mixed with three concentrations solution of chitosan to form $0.5 \%$ chitosan $+10 \mathrm{mM}$ vanillin, $1 \%$ chitosan $+10 \mathrm{mM}$ vanillin, $1.5 \%$ chitosan $+10 \mathrm{mM}$ vanillin, $0.5 \%$ chitosan $+15 \mathrm{mM}$ vanillin $1 \%$ chitosan + $15 \mathrm{mM}$ vanillin and $1.5 \%$ chitosan $+15 \mathrm{mM}$ vanillin, respectively.

\subsection{Postharvest coating treatments}

Tomato was dipped in chlorinated water that was prepared from $0.05 \%$ sodium hypochlorite for 3 mins prior to coating treatments (Ali et al., 2010). Next, the fruit was rinsed three times using running water and airdried for $1 \mathrm{hr}$. The fruits were distributed into seven lots and dipped for $1 \mathrm{~min}$ according to their coating solutions. The fruit was then dried for $2 \mathrm{hrs}$ at $26 \pm 2^{\circ} \mathrm{C} / 60 \pm 5 \%$ relative humidity $(\mathrm{RH})$. Each coating treatment carried six fruits per replicate. The treated fruits were packed in 
18-holes $0.5 \mathrm{~cm}$ diameter perforated plastic bag $18 \mathrm{~cm} \times$ $26 \mathrm{~cm}$ of $0.05 \mathrm{~mm}$ thickness. Six plastic bags were placed in a commercial corrugated fibreboard carton of $30 \mathrm{~cm} \times 25 \mathrm{~cm} \times 15 \mathrm{~cm}$ and the fruit were stored at $26 \pm 2{ }^{\circ} \mathrm{C} / 60 \pm 5 \% \mathrm{RH}$ for 25 days. Each treatment was repeated four times and analysis was carried out at every 5-day interval. In each replication, six fruit was analysed.

\subsection{Determination of disease incidence}

The incidence of the disease was measured as a percentage of fruit exhibiting symptoms of fruit rot according to the method of Khaliq et al. (2015). The incidence of the disease was determined as the number of infested fruits showing symptoms of the disease such as dots and rots of the total number of tomato fruit at each batch of storage interval. The fungal growth symptoms on the fruit surface were observed visually by using a scale where $0=$ no symptoms of decay, $1=1$ $10 \%$ decay, $2=11-25 \%$ decay, $3=26-50 \%$ decay, $4=$ $50-75 \%$ decay, $5=>75 \%$ decay. The percentage of disease was determined using diseases incidence scale by the following formula as reported by Abebe et al. (2017).

DI $(\%)=\frac{\sum(\text { DI scale }) \times(\text { Number of tomato fruit at the DI level })}{\text { Total number of tomato fruit in the treatment } \times \text { The highest score }(5)} \times 100 \%$

\subsection{Disease severity}

Tomato fruit disease severity (DS) was evaluated as described by Mohamed et al. (2017) with slight modification. Fruit disease severity was evaluated based on visible symptoms, spots, rot and decayed area on each fruit skin in each storage interval. For disease severity assessment, five points of disease severity score were used as shown in Table 1. Fruit with disease severity index scores of two, three and four were considered to have no commercial and marketing value anymore.

DS $(\%)=\frac{\sum \text { (Severity rating } \times \text { Number of tomato fruit clusters in the rating) }}{\text { Total number of tomato fruit clusters assessed } \times \text { Highest DS scale }} \times 100 \%$

\subsection{Determination of antioxidant properties}

\subsubsection{Vitamin $C$ determination}

Vitamin $\mathrm{C}$ content was determined according to the method described by Ding and Mashah (2016) using the direct colourimetric method. Fruit with peel $(5 \mathrm{~g})$ were homogenized with $45 \mathrm{~mL}$ of $2 \%$ cold metaphosphoric acid $\left(\mathrm{HPO}_{3}\right)$. The juice was filtered and added with $2 \%$ $\mathrm{HPO}_{3}$ to make up $100 \mathrm{~mL}$. Then, $1 \mathrm{~mL}$ of extract was diluted with $2 \%$ cold $\mathrm{HPO}_{3}$ to make up $5 \mathrm{~mL}$. Ten $\mathrm{mL}$ of dye solution was added and measured at $518 \mathrm{~nm}$ wavelength using a spectrophotometer (S1200, Spectrowave spectrophotometer, Cambridge, England) immediately. The concentration of tomato vitamin $\mathrm{C}$ was noted from the standard curve using vitamin $\mathrm{C}\left(\mathrm{R}^{2}=\right.$ 0.96).

\subsubsection{Lycopene determination}

The lycopene content of the tomato fruit was evaluated according to Nagat and Yamashita (1992) protocol with minor modifications. A total of $800 \mathrm{mg}$ of tomato pulp without seed was weighed and crushed using pestle and mortar. The sample pigments were extracted in $10 \mathrm{~mL}$ acetone and hexane (4:6). After the homogenization process, the extraction was transferred to a $50 \mathrm{~mL}$ separating funnel. It was allowed to stand for approximately $15 \mathrm{mins}$ to allow phase separation. Finally, the top pigment layer was collected carefully in a quartz cuvette (10 $\mathrm{mm}$ path length) and measured by using a spectrophotometer at several wavelengths (663, 645,505 and $453 \mathrm{~nm}$ ). The measured wavelengths were used to estimate total lycopene content using the following equation as described by Nagata and Yamashita (1992):

Lycopene $\mathrm{mg} / \mathrm{kg}$ fresh weight $=-0.0458 \mathrm{~A}_{663}+0.204 \mathrm{~A}_{645}$ $+0.372 \mathrm{~A}_{505}-0.0806 \mathrm{~A}_{453}$

Where $A_{663}, A_{505}$, and $A_{453}$, are absorbance at 663,505 and $453 \mathrm{~nm}$, respectively.

\subsection{Determination of total phenolic content}

\subsubsection{Sample extraction}

The extraction of tomato pulp tissue for total phenolic content (TPC) and antioxidant activities (DPPH, ABTS, and FRAP) assays followed the method described by Chiabrando and Giacalone (2019) and Petriccione et al. (2015) with slight modification. Concisely, $4 \mathrm{~g}$ of tomato tissue from each replicate were frozen in liquid $\mathrm{N}_{2}$ and ground by using a small ceramic kitchen pestle and mortar for $30 \mathrm{~s}$. The grounded tissue was dissolved in $10 \mathrm{~mL} 80 \% \quad(\mathrm{v} / \mathrm{v})$ methanol. Subsequently, the homogenate was extracted under reduced light conditions by spinning using an orbital shaker at $180 \mathrm{rpm}$ for $1 \mathrm{hr}$. After shaking, the homogenate was filtered by Whatman No.1 filter paper and transferred to a vial, which was covered by aluminium foil, and then the supernatants were kept at -

Table 1. Disease severity score of disease assessment for tomato fruit

\begin{tabular}{clc}
\hline Diseases score & & Description \\
\hline 0 & No visible symptoms on fruit & No infection \\
1 & $1-25 \%$ of the area covered by slight necrotic inoculations & Mild infection \\
2 & $26-50 \%$ of the inoculated area covered by necrotic and white fungal mycelia & Moderate infection \\
3 & $51-75 \%$ of the sample is necrotic with the presence of spore mass & Severe infection \\
4 & $>76 \%$ Necrotic tissue with fungal mass appears soft and decay & Very severe/Devastating \\
\hline
\end{tabular}


$20^{\circ} \mathrm{C}$ for antioxidant activity and capacity analyses.

\subsubsection{Total phenolic content}

The total phenolic was estimated following the method described by Kaewseejan and Siriamornpun (2015) with some modifications. Briefly, $150 \mu \mathrm{L}$ aliquot of supernatant extract and $750 \mu \mathrm{L} 10 \%$ (v/v) FolinCiocalteu reagent were mixed in test tubes that were covered by aluminium foil and incubated for $5 \mathrm{~min}$ in the dark. This followed by addition of $600 \mu \mathrm{L} 7.5 \%(\mathrm{w} / \mathrm{v})$ $\mathrm{Na}_{2} \mathrm{CO}_{3}$. The mixture was then incubated in dark for 30 mins at $26 \pm 2{ }^{\circ} \mathrm{C} / 60 \pm 5 \% \mathrm{RH}$ before measuring the absorbance at $765 \mathrm{~nm}$ by using a spectrophotometer. The TPC was expressed as milligrams of gallic acid equivalents (GAE) per $100 \mathrm{~g}$ fresh weight (FW) using gallic acid as the standard with $\mathrm{R}^{2}=0.97$, and calculated using the following equation:

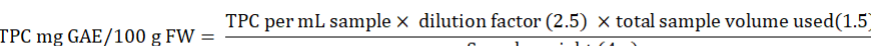
Sample weight $(4 \mathrm{~g})$

\subsection{Antioxidant activity and capacity}

2.8.1 Radical scavenging activity by using 2, 2diphenyl-1-picrylhydrazyl free radical (DPPH)

The TPC of the antioxidant activity of tomato extracts was determined using 2, 2-diphenyl-1picrylhydrazyl (DPPH) according to Briones et al. (2019) method with some modification where $1 \mathrm{mM}$ of DPPH was prepared by dissolving $0.197 \mathrm{~g}$ of DPPH powder in $1 \mathrm{~L}$ of methanol before the analysis. Then, 1 $\mathrm{mL}$ of sample extracts was applied to $1 \mathrm{~mL} 1 \mathrm{mM} \mathrm{DPPH}$ solution; the mixture was vortexed and then held at room temperature in the dark for $30 \mathrm{~min}$. After incubation, the absorbance of the mixture was measured at $517 \mathrm{~nm}$ using a spectrophotometer. The assay was performed in triplicate per sample. Meanwhile, $1 \mathrm{~mL} 80 \%$ methanol was applied as the control solution to $1 \mathrm{~mL}$ DPPH reagent. The results were expressed as percentage inhibition of DPPH, and calculated using the following equation:

DPPH inhibition $(\%)=\left(A_{0}-A_{1}\right) / A_{0} \times 100$

Where $\mathrm{A}_{0}=$ Absorbance of the control and $\mathrm{A}_{1}=$ Absorbance of sample

\subsubsection{ABTS (2, 2-azino-bis (3-ethylbenzthiazoline-6- sulfonic acid)}

The antioxidant activity of tomato was measured using 2, 2-azino-bis, 3-ethylbenzthiazoline-6-sulfonic acid according to the method of Briones et al. (2019) with slight modification. ABTS was formed by reacting $7 \mathrm{mM}$ ABTS aqueous solution with $2.45 \mathrm{mM}$ of potassium per sulphate at $26 \pm 2^{\circ} \mathrm{C} / 60 \pm 5 \% \mathrm{RH}$ for $16 \mathrm{~h}$ in the dark. This solution was diluted in ethanol (around $1: 89 \mathrm{v} / \mathrm{v}$ ) before the test and equilibrated at $30^{\circ} \mathrm{C}$ to provide an absorbance of $0.700 \pm 0.02$ at $734 \mathrm{~nm}$. The addition of $1 \mathrm{~mL}$ diluted ABTS solution in ethanol to 10 $\mu \mathrm{L}$ sample extract was incubated at $30^{\circ} \mathrm{C}$ for $6 \mathrm{~min}$ before absorbance. The inhibition percentage for the blank absorbance was then calculated at $734 \mathrm{~nm}$. The percentage of ABTS free radical inhibition was determined using the equation below:

ABTS inhibition $(\%)=\left(A_{0}-A_{1}\right) / A_{0} \times 100$

Where $\mathrm{A}_{0}=$ Absorbance of the control and $\mathrm{A}_{1}=$ Absorbance of sample

\subsubsection{Ferric reducing antioxidant power}

The tissue of tomato antioxidant capacity was assayed using ferric reducing antioxidant power (FRAP). The assay was prepared following Thaipong et al. (2006) method with slight modification. In FRAP assay, the FRAP reagent was freshly prepared by mixing $10 \mathrm{mM}$ 2,4,6-tris (2-pyridyl)-s-triazine (TPTZ) in $40 \mathrm{mM} \mathrm{HCl}$ solution, $300 \mathrm{mM}$ acetate buffer $\left(\mathrm{C}_{2} \mathrm{H}_{3} \mathrm{NaO}_{2} \cdot 3 \mathrm{H}_{2} \mathrm{O}\right.$, pH 3.6), and $20 \mathrm{mM}$ ferric chloride in the ratio of 1:10:1 (v/ $\mathrm{v} / \mathrm{v})$. An aliquot of $50 \mu \mathrm{L}$ sample extracts was added to $950 \mu \mathrm{L}$ of FRAP reagent and incubated in a water bath at $37^{\circ} \mathrm{C}$ for $30 \mathrm{~min}$. Absorbance was measured at $593 \mathrm{~nm}$ against a control that was prepared by adding $50 \mu \mathrm{L} 80 \%$ methanol to a $950 \mu \mathrm{L}$ FRAP reagent. The standard curve was a linear line between 0 and $800 \mathrm{mM}$ Trolox. The achieved results were expressed as $\mu \mathrm{M}$ Trolox equivalent (TE) of tomato fresh weight using a standard with $\mathrm{R}^{2}=$ 0.98 . The obtained FRAP results were expressed in $\mu \mathrm{M}$ $\mathrm{TE} / \mathrm{g}$ fresh weight and then calculated using the formula below:

FRAP $\mu \mathrm{M} \mathrm{TE} / \mathrm{g} F W=\frac{\text { TE } \mu \mathrm{M} \text { per } \mathrm{mL} \times \text { dilution factor }(2.5) \times \text { total sample volume used (10) }}{\text { Sample }}$ Sample weight (4 g)

\subsection{Experimental design and statistical analysis}

The experiments were carried out in a completely randomized design (CRD) with seven coating treatments and four replications i.e. Control (T0), 0.5\% chitosan $+10 \mathrm{mM}$ vanillin (T1), $1 \%$ chitosan $+10 \mathrm{mM}$ vanillin (T2), $1.5 \%$ chitosan $+10 \mathrm{mM}$ vanillin (T3), $0.5 \%$ chitosan $+15 \mathrm{mM}$ vanillin (T4), $1 \%$ chitosan $+15 \mathrm{mM}$ vanillin (T5) and $1.5 \%$ chitosan $+15 \mathrm{mM}$ vanillin (T6). Totally 168 fruits were used in this experiment. The obtained data were analysed using analysis of variance and mean comparisons were performed using Duncan's multiple range test (DMRT) in the significance level of $\mathrm{P} \leq 0.01$. All the analyses were conducted using statistical analysis software (SAS) version 9.4 (SAS Institute Inc., Cary, North Carolina, USA). The data in percentage was transformed using square root transformation before determining the significance level using DMRT. Pearson's correlation analyses were used to correlate antioxidants and antioxidants capacity among each other. 
The entire experiment was repeated three times and the data were pooled before analysis. However, the control fruit was discarded for analysis after day 25 due to high disease severity and decay.

\section{Results}

\subsection{Disease incidence and diseases severity}

Disease's incidence and severity are measuring tools that indicate disease development in the fruit. In the present study, Table 2 shows a significant interaction between coating treatment and storage days in the disease incidence and disease severity of tomato fruit.

Figure 1 shows that there was no significant difference in disease incidence among treatments on day 0 as there was no disease incidence occurred during this period of time. However, by day 5, control started to

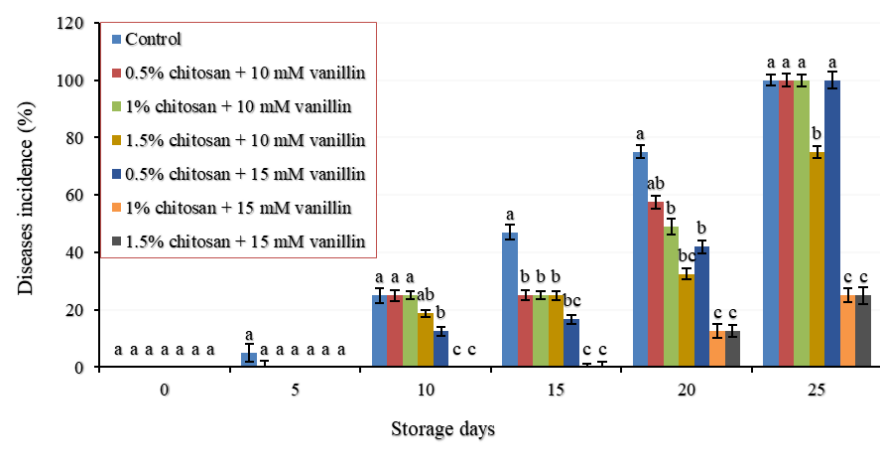

Figure 1. Effects of coating treatment on disease incidence of tomato fruit stored at $26 \pm 2{ }^{\circ} \mathrm{C}$ and $60 \pm 5 \%$ relative humidity for 25 days. Bars with different letters notation in each storage day differed significantly by DMRT $\mathrm{P} \leq 0.01$. Vertical bars indicate the standard error of means for four replicates. Prior to analysis, the data were square-root transformed while non-transformed means were shown $(\mathrm{n}=24)$

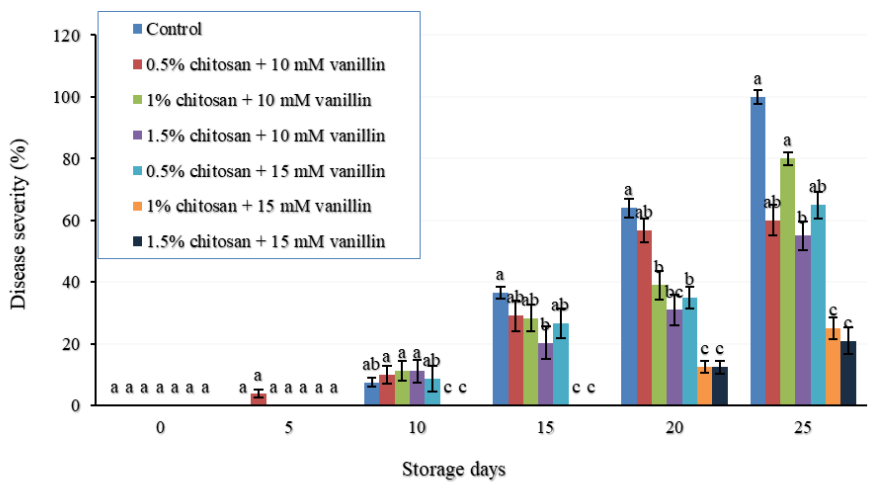

Figure 2. Effects of coating treatment on disease severity of tomato fruit stored at $26 \pm 2{ }^{\circ} \mathrm{C}$ and $60 \pm 5 \%$ relative humidity for 25 days. Bars different letters notation in each storage day differed significantly by DMRT at $\mathrm{P} \leq 0.01$. Vertical bars indicate the standard error of means for four replicates. Prior to analysis, the data were square-root transformed while nontransformed means were shown. $(n=24)$

infect by disease but no significant difference was found at this stage. By storage day 10, the disease incidence occurred in most of the treatments except tomato fruit coated with T5 and T6. On storage day 15, although fruit coated with $\mathrm{T} 5$ and $\mathrm{T} 6$ have infected by a disease, the disease incidence was much lower than control and those coated with T1, T2, T3 and T4. This trend continued until the end of storage day. However, at day 25 control fruit and those coated with T1, T2 and T4 were $100 \%$ infected by diseases incidence.

\subsection{Antioxidants}

\subsubsection{Vitamin C content}

There was a significant interaction between treatments and storage days on vitamin $\mathrm{C}$ content during storage (Table 3).

Table 2. Main and interaction effects of different coating treatments and storage days on disease incidence and severity of tomato fruit stored at $26 \pm 2{ }^{\circ} \mathrm{C}$ and $60 \pm 5 \%$ relative humidity for 25 days

\begin{tabular}{lcc}
\hline Factor & Disease incidence (\%) & Disease severity (\%) \\
\hline Treatment & $37.36^{\mathrm{a}}$ & $29.12^{\mathrm{a}}$ \\
Control & $37.42^{\mathrm{a}}$ & $21.49^{\mathrm{ab}}$ \\
$0.5 \%$ chitosan $+10 \mathrm{mM}$ vanillin & $31.50^{\mathrm{ab}}$ & $19.71^{\mathrm{b}}$ \\
$1 \%$ chitosan $+10 \mathrm{mM}$ vanillin & $29.34^{\mathrm{ab}}$ & $18.46^{\mathrm{b}}$ \\
$1.5 \%$ chitosan $+10 \mathrm{mM}$ vanillin & $28.48^{\mathrm{ab}}$ & $20.33^{\mathrm{ab}}$ \\
$0.5 \%$ chitosan $+15 \mathrm{mM}$ vanillin & $6.69^{\mathrm{c}}$ & $2.45^{\mathrm{d}}$ \\
$1.0 \%$ chitosan $+15 \mathrm{mM}$ vanillin & $6.69^{\mathrm{c}}$ & $1.46^{\mathrm{d}}$ \\
$1.5 \%$ chitosan $+15 \mathrm{mM}$ vanillin & & \\
Storage days & $0.00^{\mathrm{d}}$ & $0.00^{\mathrm{d}}$ \\
0 & $0.81^{\mathrm{d}}$ & $0.79^{\mathrm{c}}$ \\
5 & $15.27^{\mathrm{c}}$ & $6.75^{\mathrm{b}}$ \\
10 & $23.45^{\mathrm{bc}}$ & $12.78^{\mathrm{b}}$ \\
15 & $36.85^{\mathrm{b}}$ & $28.84^{\mathrm{ab}}$ \\
20 & $75.120^{\mathrm{a}}$ & $55.57^{\mathrm{a}}$ \\
25 & & $* *$ \\
Interaction & $* *$ & \\
Treatment* Storage days & ${ }^{\mathrm{a}}$ & \\
\hline
\end{tabular}

Means values in a column followed by different letters indicate significantly different according to Duncan's multiple range test at $\mathrm{P}<0.01$. ** Significant at $\mathrm{P} \leq 0.01$. $(\mathrm{n}=24)$ 
Table 3. Main and interaction effects of different coating treatments and storage days on vitamin $\mathrm{C}$ content, lycopene and Total phenolic content of tomato fruit stored at $26 \pm 2^{\circ} \mathrm{C}$ and $60 \pm 5 \%$ relative humidity for 25 days

\begin{tabular}{lccc}
\hline Factor & $\begin{array}{c}\text { Vitamin C content } \\
(\mathrm{mg} / 100 \mathrm{~g} \mathrm{FW})\end{array}$ & $\begin{array}{c}\text { Lycopene } \\
(\mathrm{mg} / \mathrm{kg} \mathrm{FW})\end{array}$ & $\begin{array}{c}\text { Total phenolic content } \\
(\mathrm{mg} \text { GAE/100 g FW })\end{array}$ \\
\hline Treatment & $37.19^{\mathrm{a}}$ & $38.77^{\mathrm{a}}$ & $77.96^{\mathrm{a}}$ \\
Control & $37.69^{\mathrm{a}}$ & $39.16^{\mathrm{a}}$ & $80.53^{\mathrm{a}}$ \\
$0.5 \%$ chitosan $+10 \mathrm{mM}$ vanillin & $37.61^{\mathrm{a}}$ & $36.74^{\mathrm{a}}$ & $78.06^{\mathrm{a}}$ \\
$1 \%$ chitosan $+10 \mathrm{mM}$ vanillin & $35.04^{\mathrm{b}}$ & $34.06^{\mathrm{b}}$ & $73.05^{\mathrm{b}}$ \\
$1.5 \%$ chitosan $+10 \mathrm{mM}$ vanillin & $37.31^{\mathrm{a}}$ & $37.66^{\mathrm{ab}}$ & $72.73^{\mathrm{b}}$ \\
$0.5 \%$ chitosan $+15 \mathrm{mM}$ vanillin & $31.67^{\mathrm{c}}$ & $29.93^{\mathrm{c}}$ & $54.86^{\mathrm{c}}$ \\
$1.0 \%$ chitosan $+15 \mathrm{mM}$ vanillin & $30.81^{\mathrm{c}}$ & $28.68^{\mathrm{c}}$ & $52.41^{\mathrm{c}}$ \\
$1.5 \%$ chitosan $+15 \mathrm{mM}$ vanillin & & & \\
Storage days & $31.72^{\mathrm{bc}}$ & $16.71^{\mathrm{d}}$ & $49.53^{\mathrm{d}}$ \\
0 & $33.07^{\mathrm{b}}$ & $19.96^{\mathrm{d}}$ & $50.40^{\mathrm{d}}$ \\
5 & $33.06^{\mathrm{b}}$ & $29.50^{\mathrm{c}}$ & $58.34^{\mathrm{c}}$ \\
10 & $33.97^{\mathrm{b}}$ & $34.60^{\mathrm{b}}$ & $69.48^{\mathrm{b}}$ \\
15 & $36.74^{\mathrm{b}}$ & $43.84^{\mathrm{a}}$ & $86.14^{\mathrm{a}}$ \\
20 & $40.47^{\mathrm{a}}$ & $44.96^{\mathrm{a}}$ & $89.23^{\mathrm{a}}$ \\
25 & $* *$ & $* *$ & $* *$ \\
Interaction & & & \\
Treatment* Storage days & & & \\
\hline
\end{tabular}

Means values in a column followed by different letters indicate significantly different according to Duncan's multiple range test at $\mathrm{P}<0.01$. **Significant at $\mathrm{P} \leq 0.01$. $(\mathrm{n}=24)$

Figure 3 displays that at storage day 10, fruit treated with $\mathrm{T} 5$ and $\mathrm{T} 6$ exhibited lower vitamin $\mathrm{C}$ as compared to control and those treated with T1, T2, T3, T1. However, by storage day 15, there was a significant difference between treatment and storage day, fruit coated with $\mathrm{T} 5$ and $\mathrm{T} 3 \mathrm{~h}$ has lower vitamin $\mathrm{C}$ content than other treatments. This trend sustained until the storage period of days 20 and 25 .

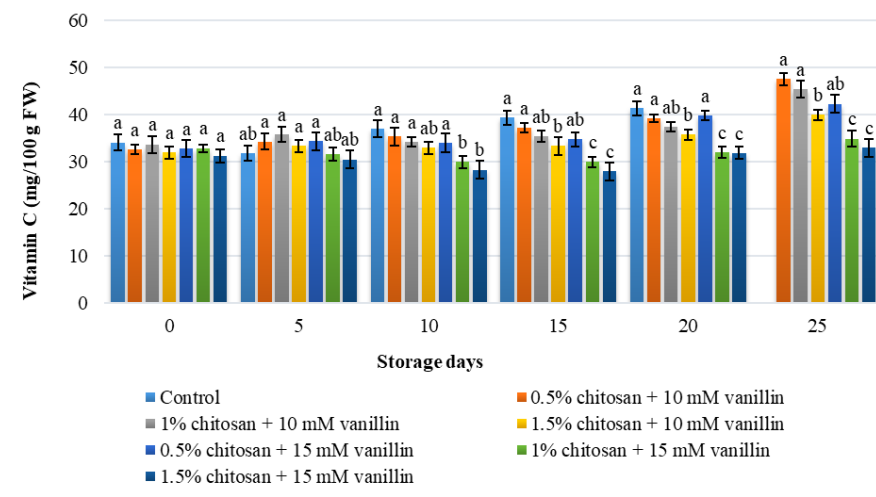

Figure 3. Effects of coating treatment on vitamin $\mathrm{C}$ content of tomato fruit stored at $26 \pm 2^{\circ} \mathrm{C}$ and $60 \pm 5 \%$ relative humidity for 25 days. Bars different letters notation in each storage day differed significantly by DMRT at $\mathrm{P} \leq 0.01$. Vertical bars indicate the standard error of means for four replicates.

\subsubsection{Lycopene}

Lycopene pigment is associated with red colour in tomatoes. Table 3 indicates that there was a significant interaction between treatments and storage days on tomato lycopene. Figure 4 exhibits there was no significant difference in tomato lycopene among treatments on days 0,5 and 10 . However, by day 15 , the lycopene content of fruit coated with $\mathrm{T} 5$ and $\mathrm{T} 6$ was lower in lycopene content than control tomato and those coated with T1, T2, T3 and T4. A similar trend was also found in tomatoes of days 20 and 25 .

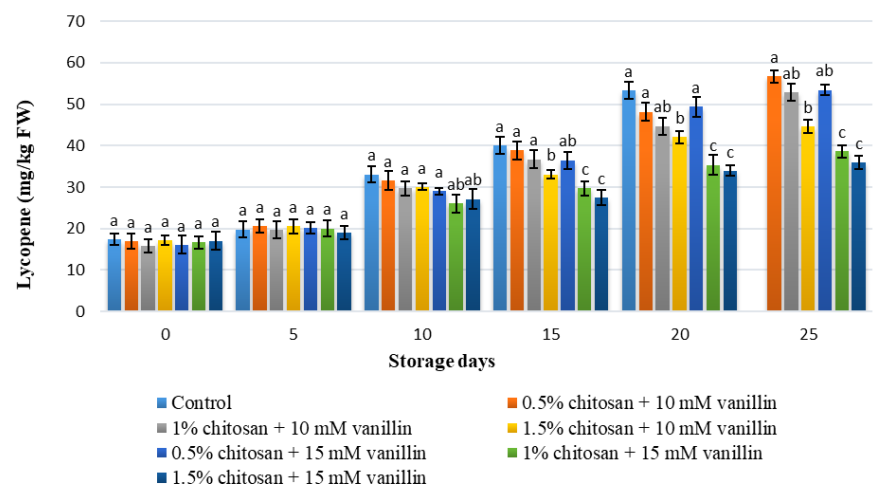

Figure 4. Effects of coating treatment on lycopene content of tomato fruit stored at $26 \pm 2^{\circ} \mathrm{C}$ and $60 \pm 5 \%$ relative humidity for 25 days. Bars different letters notation in each storage day differed significantly by DMRT at $\mathrm{P} \leq 0.01$. Vertical bars indicate the standard error of means for four replicates.

\subsection{Total phenolic content}

There was a significant interaction between coating treatments and storage days on tomato TPC (Table 3). Figure 5 shows there was no significant difference between treatment on day 0 and day 5 . By day 10 , fruit with T5 and T6 were lower in TPC than control and those coated with T1, T2, T3 and T4. This trend continued to storage days 15,20 and 25 .

\subsection{Antioxidant capacity (DPPH, ABTS, FRAP)}

Table 4 presents significant interaction effects between treatments and storage days on tomato antioxidant capacity (DPPH) during storage.

As per the mean separation in Figure 6, on days 0 


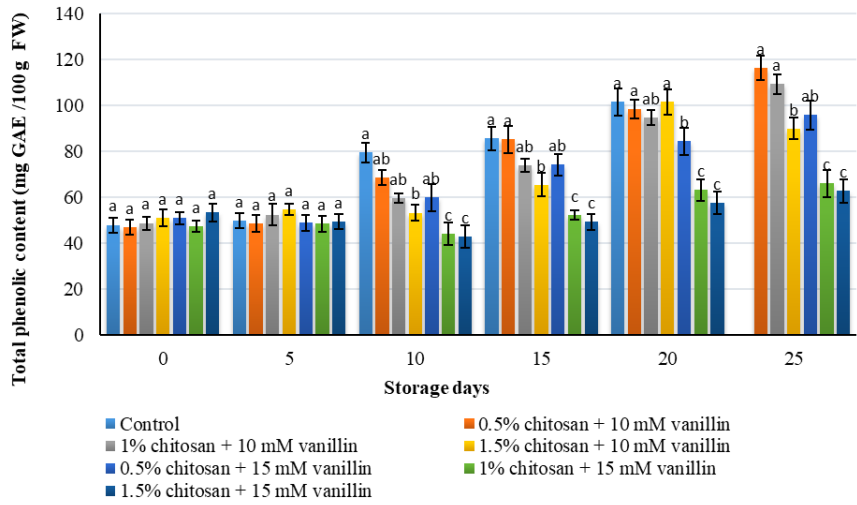

Figure 5. Effects of coating treatment on the total phenolic content of tomato fruit stored at $26 \pm 2{ }^{\circ} \mathrm{C}$ and $60 \pm 5 \%$ relative humidity for 25 days. Bars different letters notation in each storage day differed significantly by DMRT at $\mathrm{P} \leq 0.01$. Vertical bars indicate the standard error of means for four replicates.

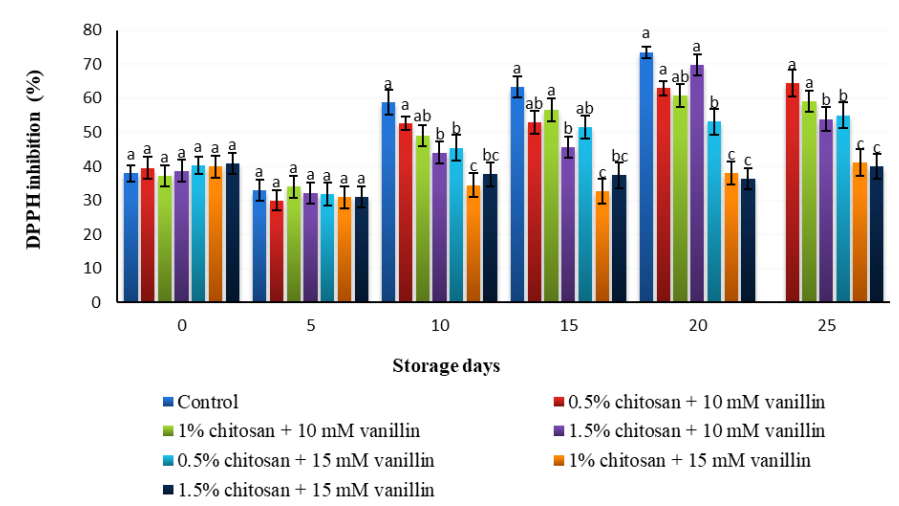

Figure 6. Effects of coating treatment on DPPH of tomato fruit stored at $26 \pm 2{ }^{\circ} \mathrm{C}$ and $60 \pm 5 \%$ relative humidity for 25 days. Bars different letters notation in each storage day differed significantly by DMRT at $\mathrm{P} \leq 0.01$. Vertical bars indicate the standard error of means for four replicates. and 5, there was no significant difference among treatments. However, on day 10, fruit coated with T5 and T6 showed lower DPPH than control and those coated with T1, T2, T3 and T4. This trend continued to the end of storage days 20 and 25 .

Table 4 indicates that there were no significant interaction effects between treatments and storage days on antioxidant capacity assayed using ABTS. However, there was a main effect among treatments on the ABTS content of tomatoes. Control and those treated with T1, $\mathrm{T} 2$, and T4 had higher ABTS than T3, T5 and T6. As storage days advanced, ABTS of tomato increased, with day 25 higher than day 0 by $43.3 \%$.

There were significant interaction effects between treatments and storage days on FRAP of tomato (Table 4). The result of Figure 7 exhibits that by day 10 fruit coated with T5 and T6 had lower FRAP than control and those coated with T1, T2, T3 and T4. This trend continued to the end of storage day 25 .

There were positive correlations among TPC, vitamin C, lycopene, DPHH, ABTS and FRAP (Table 5). From Pearson's correlation analysis, there was a significant positive correlation between TPC and vitamin $\mathrm{C}(\mathrm{r}=0.75)$, TPC and lycopene $(\mathrm{r}=0.72)$, TPC and DPPH $(r=0.76)$, TPC and ABTS $(r=0.58)$ and positive correlation between TPC and FRAP, there was as well a significant positive correlation between vitamin $\mathrm{C}$ and lycopene $(r=0.76)$, vitamin $\mathrm{C}$ and DPPH $(\mathrm{r}=0.73)$, vitamin $\mathrm{C}$ and ABTS $(\mathrm{r}=0.58)$ and positive correlation between vitamin $\mathrm{C}$ and FRAP $(\mathrm{r}=0.63)$. There was also a significant positive correlation between lycopene and DPPH $(r=0.79)$, lycopene and ABTS $(r=0.47)$ and

Table 4. Main and interaction effects of different coating treatments and storage days on antioxidants capacity of tomato fruit stored at $26 \pm 2{ }^{\circ} \mathrm{C}$ and $60 \pm 5 \%$ relative humidity for 25 days

\begin{tabular}{lccc}
\hline Factor & $\begin{array}{c}\text { DPPH } \\
\text { (\%Inhibition) }\end{array}$ & $\begin{array}{c}\text { ABTS } \\
\text { (\%Inhibition) }\end{array}$ & $\begin{array}{c}\text { FRAP } \\
\text { (mM TE/g FW) }\end{array}$ \\
\hline Treatment & & & \\
Control & $55.21^{\mathrm{a}}$ & $50.95^{\mathrm{a}}$ & $183.37^{\mathrm{a}}$ \\
$0.5 \%$ chitosan $+10 \mathrm{mM}$ vanillin & $39.29^{\mathrm{b}}$ & $53.16^{\mathrm{a}}$ & $179.49^{\mathrm{a}}$ \\
$1 \%$ chitosan $+10 \mathrm{mM}$ vanillin & $38.71^{\mathrm{b}}$ & $52.07^{\mathrm{a}}$ & $166.23^{\mathrm{b}}$ \\
$1.5 \%$ chitosan $+10 \mathrm{mM}$ vanillin & $40.37^{\mathrm{ab}}$ & $45.64^{\mathrm{b}}$ & $167.61^{\mathrm{b}}$ \\
$0.5 \%$ chitosan $+15 \mathrm{mM}$ vanillin & $42.63^{\mathrm{ab}}$ & $52.97^{\mathrm{a}}$ & $184.21^{\mathrm{ab}}$ \\
$1.0 \%$ chitosan $+15 \mathrm{mM}$ vanillin & $34.87^{\mathrm{c}}$ & $43.36^{\mathrm{b}}$ & $159.11^{\mathrm{c}}$ \\
$1.5 \%$ chitosan $+15 \mathrm{mM}$ vanillin & $33.81^{\mathrm{c}}$ & $44.49^{\mathrm{b}}$ & $156.83^{\mathrm{c}}$ \\
Storage days & & & \\
0 & $54.58^{\mathrm{a}}$ & $37.19^{\mathrm{e}}$ & $153.67^{\mathrm{b}}$ \\
5 & $27.68^{\mathrm{c}}$ & $39.55^{\mathrm{e}}$ & $133.84^{\mathrm{c}}$ \\
10 & $35.43^{\mathrm{cb}}$ & $44.99^{\mathrm{d}}$ & $145.67^{\mathrm{b}}$ \\
15 & $37.68^{\mathrm{b}}$ & $50.13^{\mathrm{c}}$ & $148.47^{\mathrm{b}}$ \\
20 & $41.19^{\mathrm{ab}}$ & $58.26^{\mathrm{ab}}$ & $161.89^{\mathrm{ab}}$ \\
25 & $44.85^{\mathrm{ab}}$ & $65.69^{\mathrm{a}}$ & $174.81^{\mathrm{a}}$ \\
Interaction & $* *$ & $\mathrm{~ns}$ & $* *$ \\
Treatment* Storage days & & & \\
\hline
\end{tabular}

Means values followed by different letters indicate significantly different according to Duncan's multiple range test $\mathrm{P}<0.01$. $* *$ Significant at $\mathrm{P} \leq 0.01$. nsNot significant. $(\mathrm{n}=24)$ 
Table 5. Pearson's correlation coefficients for TPC, vitamin C, lycopene, DPPH, ABTS and FRAP of tomato fruit stored at $26 \pm 2^{\circ} \mathrm{C}$ and $60 \pm 5 \%$ relative humidity for 25 days.

\begin{tabular}{ccccccc}
\hline & TPC & Vitamin C & Lycopene & DPPH & ABTS & FRAP \\
\hline TPC & - & & & & & \\
Vitamin C & $0.75^{* *}$ & - & & & & \\
Lycopene & $0.72^{* *}$ & $0.76^{* *}$ & - & & & \\
DPPH & $0.76^{* *}$ & $0.73^{* *}$ & $0.79^{* *}$ & - & & \\
ABTS & $0.58^{* *}$ & $0.56^{* *}$ & $0.47^{* *}$ & $0.52^{* *}$ & - & \\
FRAP & $0.74^{* *}$ & $0.63^{* *}$ & $0.73^{* *}$ & $0.76^{* *}$ & $0.54^{* *}$ & - \\
\hline
\end{tabular}

$\mathrm{TPC}=$ Total phenolic content, DPPH = 2, 2-diphenyl-1-picrylhydrazyl, ABTS = 2, 2'-azino-bis (3-ethylbenzothiazoline-6sulphonic acid) and FRAP $=$ ferric reducing antioxidant power. $* *$ Significant correlation at $\mathrm{P} \leq 0.01$.

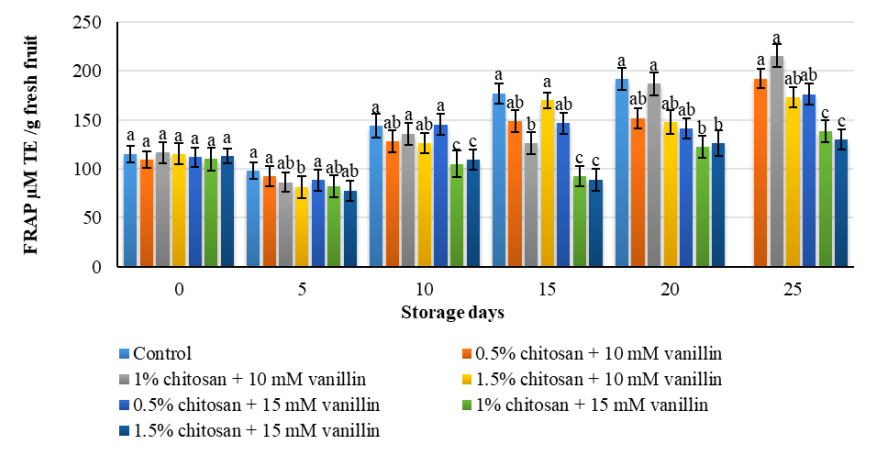

Figure 7. Effects of coating treatment on FRAP of tomato fruit stored at $26 \pm 2{ }^{\circ} \mathrm{C}$ and $60 \pm 5 \%$ relative humidity for 25 days. Bars different letters notation in each storage day differed significantly by DMRT at $\mathrm{P} \leq 0.01$. Vertical bars indicate the standard error of means for four replicates.

positive correlation between lycopene and FRAP ( $\mathrm{r}=$ 0.73 ). There was well a significant positive correlation DPPH and ABTS $(r=0.52)$ and positive correlation between DPPH and FRAP $(r=0.76)$ (Table 5).

\section{Discussion}

\subsection{Effects of edible coating on diseases incidence and diseases severity}

Postharvest fungal disease is one of the important factors that restrict the storage period and marketing life of perishable fruit (Hossain et al., 2010), and it is a major concern in influencing consumer prices, requirements and mode of transportation, and even result in serious economic losses worldwide (Zhang et al., 2019). Severity is the quantity of disease affecting entities within a tomato fruit, where fruit will lose quantity, quality, and marketing value when severity has occurred and progressed (Zhang et al., 2017). The capacity of chitosan coating in inhibiting the growth of several fungi has been reported for a wide variety of harvested commodities (Garcí, 2013). This was in agreement with Xing et al. (2016) who found that chitosan coating formed a thin film on fruit surface and inhibit the growth of inoculated bacteria, yeast and moulds. This inhibition could due to chitosan activity in the disturbing cell membrane of pathogen that led to intracellular leakage and finally cells death (Matica et al., 2017). According to
Chang (2019), chitosan could interfere with both cell membranes and cell walls of a pathogen and inactivated the function of the genetic material of the pathogen.

The interaction was significant between treatment and storage days on tomato fruit diseases incidence and severity (Figures 1 and 2). Generally, the present study found that the disease incidence and severity increased with the advancement of the storage period. Coating significantly affected the percentage of disease incidence and severity during the storage period. As the storage period progressed, control fruit and those treated with a low concentration of chitosan and vanillin $\mathrm{T} 1$ and $\mathrm{T} 4$ showed severe infection and reflected as greater disease incidence. At the end of storage day 25, the disease incidence and severity increased by 75 and $55.17 \%$, respectively, as compared to the initial day of storage. While a high concentration of chitosan and vanillin T5 and $1.5 \%$ chitosan $+15 \mathrm{mM}$ inhibited the progression of diseases in tomato fruit as found in Figures 1 and 2. By increasing the concentration of chitosan and vanillin, diseases incidence and severity decreased. However, by day 25, coating of $\mathrm{T} 5$ and $\mathrm{T} 6$ inhibited diseases incidence by 75 and $74.16 \%$, respectively while severity was by 75 and $79 \%$, respectively.

The decrease of disease incidence and severity in a high concentration of coating could due to the formation of semi-permeable film around the fruit surface. This thin layer could prevent the growth of pathogens by disturbing the cell membrane that caused intracellular leakage and finally cell death of pathogens. Besides, chitosan and vanillin coating can enhance the epidermal structure of fruit and limit the spread of pathogens. Abebe and Mohammed (2017) expressed that coating could assist the cell wall to retain its integrity against fungal attack and help in delaying pathogenic infection. This finding was in agreement with Sikder et al. (2019) who found mature green banana coated with $1 \%$ chitosan and stored at room temperature $\left(28 \pm 2^{\circ} \mathrm{C}\right)$ has remarkably inhibited disease incidence and severity than fruit coated with $0.5 \%$ chitosan. Hewajulige and Sivakumar (2007) 
also found that anthracnose disease incidence and severity on papaya fruit coated with $1 \%$ chitosan was 4.5 times lowered as compared to those coated with $0.5 \%$ chitosan. Taghinezhad and Sharabiani (2018) found out similar finding that $1.5 \%$ chitosan coating reduced the decay rate in cucumber and bell pepper than those coated with $0.5 \%$ chitosan. In the current study, the film created by the higher concentration of $\mathrm{T} 5$ and $\mathrm{T} 6$ coating has slowed down the ripening and senescence process of tomato fruit and therefore disease incidence and severity were less in this tomato fruit during 25 days of storage at $26 \pm 2^{\circ} \mathrm{C}$ and $60 \pm 5 \% \mathrm{RH}$.

\subsection{Antioxidant properties}

\subsubsection{Vitamin $C$ content}

The result of Figure 3 shows a significant interaction effect between treatments and storage days in vitamin $\mathrm{C}$ content of tomato. By increasing chitosan and vanillin concentration, the vitamin $\mathrm{C}$ content of tomato decreased (Table 3). Hence, fruit with T5 and T6 had lower vitamin $\mathrm{C}$ content than control and those coated with T1, T2, T3 and T4. By storage day 25, the vitamin $\mathrm{C}$ content of fruit with T5 and T6 was 34 and 38\%, respectively lower than fruit coated with $\mathrm{T} 1$.

This might be due to the coating of chitosan that has inhibited vitamin $\mathrm{C}$ synthesis and delayed the changes in vitamin $\mathrm{C}$ content. In line with this study, Petriccione et al. (2015) reported that $1.5 \%$ chitosan-coated sweet cherry showed lower vitamin $\mathrm{C}$ content than control during storage at $2{ }^{\circ} \mathrm{C}$ for 14 days. Similarly, Kibar and Sabir (2018) reported that vitamin C content in tomato coated with $1 \%$ chitosan decreased during storage at $21^{\circ}$ C. The film created by a high concentration of T 5 and T 6 coating could reduce oxygen diffusion. Thus, resulting in the slow ripening and senescence process of tomato and therefore, vitamin $\mathrm{C}$ content is retained at a lower level in this fruit during 25 days of storage at $26 \pm 2{ }^{\circ} \mathrm{C} / 60 \pm 5 \%$ RH.

\subsubsection{Lycopene}

Lycopene gives characteristic of red colour and due to its strong colour and non-toxicity, it is a good food colouring (Alda et al., 2009). There was a significant interaction between treatments and storage days (Figure 4). From day 15 until the end of storage day 25, fruit coated with T5 and T6 had lower lycopene content than control fruit and those coated with T1, T2, T3 and T4. At the end of storage day 25 , fruit coated with $\mathrm{T} 5$ and $\mathrm{T} 6$ has 39.72 and $44.02 \%$ lower lycopene content than fruit coated with $\mathrm{T} 1$. This may duet coatings reduce the respiration rate and ethylene production of fruit by forming a barrier around its surface. In line with this study Mandal et al. (2018) reported that 2\% chitosan coating had lower lycopene in fruit than those coated with $0.5 \%$ chitosan during 22 days of storage in ambient conditions $\left(25 \pm 2^{\circ} \mathrm{C}\right)$. Abebe et al. (2017) also found out that $3 \%$ chitosan coating reduced lycopene content in fruit than those coated with $0.5 \%$ chitosan during storage at $22 \pm 1^{\circ} \mathrm{C} / 75 \pm 1 \% \mathrm{RH}$. It has been claimed that the formation of lycopene depends on the rate of respiration and ethylene production during storage. This could explain fruit coated with a higher concentration of coatings such as T5 and T6 have lower lycopene content than other coatings.

\subsection{Total phenolic content}

Phenolic compounds are one of the major contributors to the antioxidant properties of fresh products (Pinheiro et al., 2016). Phenolic compounds are important plant elements with redox properties that are responsible for the antioxidant activity, where the hydroxyl groups in plant extracts are responsible for facilitating free radical scavenging (Aryal et al., 2019). Plants need phenolic compounds for pigmentation, reproduction, growth, and resistance to pathogens (Lattanzio et al., 2006). Phenolic compound possesses antioxidants and serves as protective mechanisms in fruit (Khaliq et al., 2016). As per the result of Figure 5, there was a significant interaction effect between treatments and storage days. The result indicates that fruit coated with T5 and T6 had lower total phenolic content (TPC) than control and fruit that coated with T1, T2, T3 and T4. However, by storage day 25, T5 and $\mathrm{T} 6$ had 56.13 and $49.5 \%$ lower TPC than fruit coated with T1.

The increase of phenolic levels in low concentration chitosan and vanillin coating (T1 and T4) might be due to the higher rate of respiration that caused degradation of certain phenolic compounds. In agreement with the current study, Petriccione et al. (2015) found that TPC was higher in sweet cherry coated with $0.5 \%$ chitosan than fruit treated with $1 \%$ chitosan during 14 days of storage at $2^{\circ} \mathrm{C}$. Yang et al. (2014) also reported that TPC content was lower in blueberry coated with $2 \%$ chitosan than those coated with $0.5 \%$ chitosan during storage at $2 \pm 1^{\circ} \mathrm{C} / 95 \pm 2 \% \mathrm{RH}$ for 35 days. In the present study, the barrier created by the higher concentration of coating $\mathrm{T} 5$ and T6 has slowed down the ripening and senescence processes and suppressed abiotic stresses on produce which modified the metabolism of tomatoes. Therefore, the TPC was lesser in this fruit.

\subsection{Antioxidant capacity (DPPH, ABTS, FRAP)}

In the present study, Figure 6 shows significant interaction between treatments and storage days on tomato DPPH. At the end of storage, fruit coated with T5 and T6 had 45.06 and 50.30\% lower DPPH than control 
and those coated with $\mathrm{T} 1, \mathrm{~T} 2$ and $\mathrm{T} 4$.

A study by Kou et al. (2014) reported that DPPH in pear fruit coated with $2 \%$ chitosan decreased during storage. Zahedi et al. (2019) also found out that DPPH in mango fruit coated with $2 \%$ chitosan decreased during storage for 24 days at $15 \pm 2{ }^{\circ} \mathrm{C} / 85-90 \% \mathrm{RH}$. In line with this study Zam (2019) found out that DPPH of sweet cherry coated with $1 \%$ chitosan decreased during 20 days of storage. In the present study, the film created by the high concentration of coating $\mathrm{T} 5$ and $\mathrm{T} 6$ has caused modification to internal atmosphere modification of phenolic compounds of tomato and therefore DPPH is lower in this fruit.

Table 4 shows the coating of T1, T2, T3, T4, T5 and T6 affected fruit antioxidant capacity (ABTS). Fruit coated with T3, T5, T6 had lower ABTS than control, and those coated with $\mathrm{T} 1$ and $\mathrm{T} 4$ during entire storage. The increase in antioxidant capacity might occur due to faster senescence and decay of tomatoes. In line with this study, Martínez et al. (2018) found that strawberry coated with $1.5 \%$ chitosan had lower ABTS than fruit coated with $0.5 \%$ chitosan and $0.5 \%$ chitosan $+1 \%$ Thymus capitatus essential oil during 15 days of storage. Hosseini et al. (2018) also reported that ABTS of banana treated with $1 \%$ chitosan decreased when stored at $15 \pm 2^{\circ}$ $\mathrm{C} / 85-90 \% \mathrm{RH}$ for 20 days. In the current study, the barrier formed by the high concentration of coating T5 and $\mathrm{T} 6$ has slowed down the senescence process and reduced decay in tomato and thus ABTS is lesser in this fruit.

Figure 7 shows significant interaction between treatments and storage days on tomato FRAP. However, fruit coated with T5 and T6 had lower FRAP than control and fruit coated with T1, T2, T3 and T4 during entire storage. As storage days advanced, FRAP increased, where FRAP at day 25 was $13 \%$ higher than day 0 . However, by storage day 25 , fruit coated with T5 and T6 has lower FRAP than control and fruit coated with T1, T2, T3 and T4.

This finding might be due to the formation of a protective barrier on the surface of fresh fruit and inhibited the decline of antioxidant activity (Kou et al., 2014). In agreement with this study's finding, Ghasemnezhad et al. (2013) found out that the antioxidant capacity (FRAP) of pomegranate treated with $1 \%$ chitosan decreased during 12 days of storage at $4{ }^{\circ} \mathrm{C}$. In line with this study, FRAP in strawberry treated with $1.5 \%$ chitosan and stored at $10^{\circ} \mathrm{C}$ for 12 days has decreased (Wang and Gao, 2013). Tomato coated with $10 \%$ gum Arabic had lower FRAP than those treated with 0 and $5 \%$ gum Arabic stored at $20^{\circ} \mathrm{C} / 80-90 \% \mathrm{RH}$ for 20 days (Ali et al., 2013). Therefore, a barrier formed by the higher concentration of coating has slowed down the senescence process and reduced decay in tomatoes thus led to lower FRAP in the present study.

There was a significant positive correlation between antioxidants i.e. TPC, vitamin $\mathrm{C}$, lycopene and antioxidant capacity (DPPH, ABTS and FRAP) in tomato fruit treated with chitosan and vanillin during entire storage (Table 5). This was in agreement with Lugasi and Helyes (2006), who found a positive correlation TPC and lycopene content $(r=0.72)$ in tomato fruit during ripening. A similar finding was also found out by Izawa et al. (2018) where the correlation was positive between TPC and vitamin $\mathrm{C}(\mathrm{r}=0.75)$ in tomato fruit. In line with this study, Alda (2009) also found a positive correlation between TPC and lycopene $(r=0.72)$ in tomato fruit. In agreement with the study by Palonen and Weber (2019) who reported a strong positive correlation between TPC and vitamin $\mathrm{C}(\mathrm{r}=$ 0.75). A similar result was also reported by Floegel et al. (2011) that there was positive significance in apple fruit that the correlation between TPC and DPPH $(r=0.76)$, significant correlation TPC and ABTS $(r=0.58)$ and significant correlation of TPC and FRAP $(\mathrm{r}=0.74)$. In line with this study, Fu et al. (2010) also found a highly significant positive correlation between TPC and antioxidant capacity (FRAP) $(\mathrm{r}=0.74)$ in Ficus benjamina. The finding of this study indicated that TPC is the major contributor to tomato fruit antioxidants and antioxidant capacity.

\section{Conclusion}

Chitosan combines with vanillin in different concentrations was used as edible coatings to examine its effect on the antioxidant and antioxidant properties of tomato. Results exhibit that a higher concentration of chitosan and vanillin coatings $1.5 \%$ chitosan $+15 \mathrm{mM}$ vanillin has retained low antioxidant content (TPC, vitamin $\mathrm{C}$ and lycopene content), antioxidant activity, and capacity of tomato during storage at $26 \pm 2{ }^{\circ} \mathrm{C} / 60 \pm 5 \%$ $\mathrm{RH}$ for 25 days. At day 25 mentioned coating agent retained low vitamin $\mathrm{C}$ up to $30.47 \%$, TPC $50 \%$, DPPH $48.21 \%$, ABTS $9.82 \%$ and FRAP up to $33.65 \%$ as compared to control and fruits those coated with $0.5 \%$ chitosan $+10 \mathrm{mM}$ vanillin. This study indicates that $1.5 \%$ chitosan $+15 \mathrm{mM}$ vanillin is recommended to coat tomato when a refrigeration facility is not available during marketing.

\section{Conflict of interest}

The authors declare that they have no known competing financial interests or personal relationships that could have influenced the work reported in this paper. 


\section{Acknowledgments}

The authors wish to thank from Arakozia Institute of Higher Education for the financial support to publish this work open-access comes from the Food Research Journal. The authors are grateful for this support.

\section{References}

Abebe, Z., Tola, Y.B. and Mohammed, A. (2017). Effects of edible coating materials and stages of maturity at harvest on storage life and quality of tomato (Lycopersicon esculentum Mill.) fruits. African Journal of Agricultural Research, 12 (8), 550-565. https://doi.org/10.5897/ AJAR2016.11648

Alda, L.M., Gogoa, I. and Despina-maria, B. (2009). Lycopene content of tomatoes and tomato products. Journal of Agroalimentary Processes and Technologies, 15(4), 540-542.

Ali, A., Maqbool, M., Alderson, P.G. and Zahid, N. (2013). Effect of gum Arabic as an edible coating on antioxidant capacity of tomato (Solanum lycopersicum L.) fruit during storage. Postharvest Biology and Technology, 76, 119-124. https:// doi.org/10.1016/j.postharvbio.2012.09.011

Ali, A., Maqbool, M., Ramachandran, S. and Alderson, P.G. (2010). Gum Arabic as a novel edible coating for enhancing shelf life and improving postharvest quality of tomato (Solanum lycopersicum L.) fruit. Postharvest Biology and Technology, 58(1), 42 -47. https://doi.org/10.1016/ j.postharvbio.2010.05.005

Arah, I.K., Amaglo, H., Kumah, E.K. and Ofori, H. (2015). Preharvest and postharvest factors affecting the quality and shelf life of harvested tomatoes: a mini review. Journal of Biology, Agriculture and Healthcare, 5(16), 78-88. https:// doi.org/10.1155/2015/478041.

Aryal, S., Baniya, M.K., Danekhu, K., Kunwar, P., Gurung, R. and Koirala, N. (2019). Total phenolic content, flavonoid content and antioxidant potential of wild vegetables from Western Nepal. Plants, 8(4), 96-108. https://doi.org/10.3390/plants8040096

Bal, E. (2019). Influence of chitosan-based coatings with UV irradiation on quality of strawberry fruit during cold storage. Turkish Journal of Agriculture-Food Science and Technology, 7(2), 275-281. https:// doi.org/10.24925/turjaf.v7i2.275-281.2252

Briones-Labarca, V., Giovagnoli-Vicuna, C. and CanasSarazua, R. (2019). Optimization of extraction yield, flavonoids and lycopene from tomato pulp by high hydrostatic pressure-assisted extraction. Food Chemistry, 278, 751-759. https://doi.org/10.1016/ j.foodchem.2018.11.106

Ciriminna, R., Fidalgo, A., Meneguzzo, F., Parrino, F., Ilharco, L.M. and Pagliaro, M. (2019). Vanillin: The case for greener production driven by sustainability megatrend. Chemistry Open, 8(6), 660-667. https:// doi.org/10.1002/open.201900083

Ding, P. and Mashah, N.C. (2016). Growth, maturation and ripening of underutilized Carissa congesta fruit. Fruits, 71(3), 171-176. https://doi.org/10.1051/ fruits/2016005.

Floegel, A., Kim, D.O., Chung, S.J., Koo, S.I. and Chun, O.K. (2011). Comparison of ABTS/DPPH assays to measure antioxidant capacity in popular antioxidantrich US foods. Journal of Food Composition and Analysis, 24(7), 1043-1048. https://doi.org/10.1016/ j.jfca.2011.01.008

Forni, C., Facchiano, F., Bartoli, M., Pieretti, S., Facchiano, A., D'Arcangelo, D. and Tabolacci, C. (2019). Beneficial role of phytochemicals on oxidative stress and age-related diseases. BioMed Research International, 20(19), 1-16. https:// doi.org/10.1155/2019/8748253

Ghasemnezhad, M., Zareh, S., Rassa, M. and Sajedi, R.H. (2013). Effect of chitosan coating on maintenance of aril quality, microbial population and PPO activity of pomegranate (Punica granatum L. cv. Tarom) at cold storage temperature. Journal of the Science of Food and Agriculture, 93(2), 368-374. http://dx.doi.org/10.1016/j.tifs.2015.10.010.

Hewajulige, I.G.N., Sivakumar, D., Sultanbawa, Y., Wilson Wijeratnam, R.S. and Wijesundera, R.L.C. (2005). Effect of chitosan coating on the control of anthracnose and overall quality retention of papaya (Carica papaya L.) during storage. In Proceedings of I International Symposium on Papaya 740. Genting Highlands, Malaysia.

Hossain, M.T., Hossain, S.M.M., Bakr, M.K., Rahman, A.M. and Uddin, S.N. (2010). Survey on major diseases of vegetable and fruit crops in Chittagong region. Bangladesh Journal of Agricultural Research, 35(3), 423-429. https://doi.org/10.3329/ bjar.v35i3.6449

Hosseini, M.S., Zahedi, S.M., Abadía, J. and Karimi, M. (2018). Effects of postharvest treatments with chitosan and putrescine to maintain quality and extend shelf-life of two banana cultivars. Food Science and Nutrition, 6(5), 1328-1337. https:// doi.org/10.1002/fsn3.662

Ippolito, A. and Sanzani, S.M. (2010). Control of postharvest decay by the integration of pre-and postharvest application of non-chemical compounds. Acta Horticulturae, 905, 135-143. https:// 
doi.org/10.17660/ActaHortic.2011.905.13

Jing, Y., Huang, J. and Yu, X. (2019). Maintenance of the antioxidant capacity of fresh-cut pineapple by procyanidin-grafted chitosan. Postharvest Biology and Technology, 154, 79-86. https://doi.org/10.1016/ j.postharvbio.2019.04.022

Kaewseejan, N. and Siriamornpun, S. (2015). Bioactive components and properties of ethanolic extract and its fractions from Gynura procumbens leaves. Industrial Crops and Products, 74, 271-278. https://doi.org/10.1016/j.indcrop.2015.05.019

Khaliq, G., Mohamed, M.T.M., Ali, A., Ding, P. and Ghazali, H.M. (2015). Effect of gum arabic coating combined with calcium chloride on physicochemical and qualitative properties of mango (Mangifera indica L.) fruit during low temperature storage. Scientia Horticulturae, 190, 187-194. https://doi.org/10.1016/j.scienta.2015.04.020

Khaliq, G., Mohamed, M.T.M., Ghazali, H.M., Ding, P. and Ali, A. (2016). Influence of gum arabic coating enriched with calcium chloride on physiological, biochemical and quality responses of mango (Mangifera indica L.) fruit stored under low temperature stress. Postharvest Biology and Technology, 111, 362-369. https://doi.org/10.1016/ j.postharvbio.2015.09.029

Kibar, H.F. and Sabir, F.K. (2018). Chitosan coating for extending postharvest quality of tomatoes (Lycopersicon esculentum Mill.) maintained at different storage temperatures. AIMS Agriculture and Food, 3(2), 97-108. https://doi.org/10.3934/ agrfood.2018.2.97

Kore, Vijaykumar, T.K., Sima, S.T. and Kabir, J. (2017). Application of edible coatings on fruits and vegetables." Imperial Journal of Interdisciplinary Research, 3(1), 591-603.

Kumari, S., Stecher, G. and Tamura, K. (2016). MEGA7: molecular evolutionary genetics analysis version 7.0 for bigger datasets. Molecular Biology and Evolution, 33(7), 1870-1874. https://doi.org/10.1093/ molbev/msw054

Kou, X.H., Guo, W.L., Guo, R.Z., Li, X.Y. and Xue, Z.H. (2014). Effects of chitosan, calcium chloride, and pullulan coating treatments on antioxidant activity in pear cv. "Huang guan" during storage. Food and Bioprocess Technology, 7(3), 671681. https://doi.org/10.1007/s11947-013-1085-9

Lattanzio, V., Lattanzio, V.M. and Cardinali, A. (2006). Role of phenolics in the resistance mechanisms of plants against fungal pathogens and insects. Phytochemistry: Advances in Research, 661 (2), 23-67.
Liu, Z., Ren, Z., Zhang, J., Chuang, C.C., Kandaswamy, E., Zhou, T. and Zuo, L. (2018). Role of ROS and nutritional antioxidants in human diseases. Frontiers in Physiology, 9(4), 477-486. https:// doi.org/10.3389/fphys.2018.00477

Matica, A., Menghiu, G. and Ostafe, V. (2017). Antifungal properties of chitosans. New Front. New Frontiers in Chemistry, 26(1), 55-63.

Mahfoudhi, N., Chouaibi, M. and Hamdi, S. (2014). Effectiveness of almond gum trees exudate as a novel edible coating for improving postharvest quality of tomato (Solanum lycopersicum L.) fruits. Food Science and Technology International, 20(1), 33-43. https:// doi.org/10.1177/1082013212469617

Mandal, D., Lalhmingchawii, C., Hazarika, T.K. and Shukla, A.C. (2018). Effect of chitosan, wax and particle film coating on shelf life and quality of tomato cv. Samrudhi at ambient storage. Research Journal of Agricultural Sciences, 9(1), 111-116.

Martínez, K., Ortiz, M., Albis, A., Gilma Gutiérrez Castañeda, C., Valencia, M.E. and Grande Tovar, C.D. (2018). The effect of edible chitosan coatings incorporated with Thymus capitatus essential oil on the shelf life of strawberry (Fragaria $x$ ananassa) during cold storage. Biomolecules, 8(4), 155-166. https://doi.org/10.3390/biom8040155

Mwende, R., Owino, W. and Imathiu, S. (2018). Effects of pretreatment during drying on the antioxidant properties and color of selected tomato varieties. Food Science and Nutrition, 6(2), 503511. https://doi.org/10.1002/fsn3.581

Mohamed, N.T.S., Ding, P., Kadir, J. and Ghazali, H.M. (2017). Potential of UVC germicidal irradiation in suppressing crown rot disease, retaining postharvest quality and antioxidant capacity of Musa AAA "Berangan" during fruit ripening Food Science and Nutrition, 5(5), 967-980. https://doi.org/10.1002/ fsn3.482.

Nagata, M. and Yamashita, I. (1992). Simple method for simultaneous determination of chlorophyll and carotenoids in tomato fruit. Nippon Shokuhin Kogyo Gakkaishi, 39(10), 925-928. https://doi.org/10.3136/ nskkk1962.39.925

Nor, S.M. and Ding, P. (2020). Trends and advances in edible biopolymer coating for tropical fruit: A Review. Food Research International, 134, 109208. https://doi.org/10.1016/j.foodres.2020.109208

Palonen, P. and Weber, C. (2019). Fruit color stability, anthocyanin content, and shelf life were not correlated with ethylene production rate in five primocane raspberry genotypes. Scientia 
Horticulturae, 247, 9-16. https://doi.org/10.1016/ j.scienta.2018.11.088

Petriccione, M., De Sanctis, F., Pasquariello, M.S., Mastrobuoni, F., Rega, P., Scortichini, M. and Mencarelli, F. (2015). The effect of chitosan coating on the quality and nutraceutical traits of sweet cherry during postharvest life. Food and Bioprocess Technology, 8(2), 394-408. https://doi.org/10.1007/ s11947-014-1411-x

Pinheiro, J.C., Alegria, C.S., Abreu, M.M., Gonçalves, E.M., and Silva, C.L. (2016). Evaluation of alternative preservation treatments (water heat treatment, ultrasounds, thermosonication and UV-C radiation) to improve safety and quality of whole tomato. Food and Bioprocess Technology, 9(6), 924935. https://doi.org/10.1007/s11947-016-1679-0

Safari, Z.S., Ding, P., Juju Nakasha, J. and Yusoff, S.F. (2020). Combining Chitosan and Vanillin to Retain Postharvest Quality of Tomato Fruit during Ambient Temperature Storage. Coatings, 10(12), 1222. https://doi.org/10.3390/coatings10121222

Safari, Z.S., Ding, P., Atif, A. and Yusoff, S.F. (2021). Antifungal Evaluation of Edible Coating Agent Against Fusarium oxysporum on Tomato. International Journal of Scientific and Technology Research, 10(2), 66-77.

Sikder, M.B.H. and Islam, M.M. (2019). Effect of shrimp chitosan coating on physico-chemical properties and shelf life extension of banana. International Journal of Engineering Technology and Sciences, 6(1), 41-54.

Suwarat Rakchoy, P.S. (2009). Antimicrobial effects of vanillin coated solution for coating paperboard intended for packaging bakery product. Asian Journal of Food and Agro-Industry, 2(4), 138-147.

Sucharitha, K.V., Beulah, A.M. and Ravikiran, K. (2018). Effect of chitosan coating on storage stability of tomatoes (Lycopersicon esculentum Mill). International Food Research Journal, 25(1), 93-99.

Taghinezhad, E. and Sharabiani, V.R. (2018). Effect of chitosan coating on some quality properties of Thomson orange during storage (a case study in Iran). Agricultural Engineering International: CIGR Journal, 20(1), 157-161.

Thaipong, K., Boonprakob, U., Crosby, K., CisnerosZevallos, L. and Byrne, D.H. (2006). Comparison of ABTS, DPPH, FRAP, and ORAC assays for estimating antioxidant activity from guava fruit extracts. Journal of Food Composition and Analysis, 19(6-7), 669-675. https://doi.org/10.1016/ j.jfca.2006.01.003
Valente, A., Albuquerque, T.G., Sanches-Silva, A. and Costa, H.S. (2011). Ascorbic acid content in exotic fruits: A contribution to produce quality data for food composition databases. Food Research International, 44(7), 2237-2242. https:// doi.org/10.1016/j.foodres.2011.02.012

Wang, S.Y. and Gao, H. (2013). Effect of chitosan-based edible coating on antioxidants, antioxidant enzyme system, and postharvest fruit quality of strawberries (Fragaria $\mathrm{x}$ aranassa Duch.). LWT-Food Science and Technology, 52(2), 71-79. https://doi.org/10.1016/ j.lwt.2012.05.003

Xing, Y., Xu, Q., Li, X., Chen, C., Ma, L., Li, S. and Che, Z. and Lin, H. (2016). Chitosan-based coating with antimicrobial agents: preparation, property, mechanism, and application effectiveness on fruits and vegetables. International Journal of Polymer Science, 20(16), 1-24. https:// doi.org/10.1155/2016/4851730

Zam, W. (2019). Effect of alginate and chitosan edible coating enriched with olive leaves extract on the shelf life of sweet cherries (Prunus avium L.). Journal of Food Quality, 20(19), 1234-1244. https://doi.org/10.1155/2019/8192964

Zahedi, S.M., Hosseini, M.S., Karimi, M. and Ebrahimzadeh, A. (2019). Effects of postharvest polyamine application and edible coating on maintaining quality of mango (Mangifera indica L.) cv. Langra during cold storage. Food Science and Nutrition, 7(2), 433-441. https://doi.org/10.1002/ fsn 3.802

Zhang, J., Liu, J., Xie, J., Deng, L., Yao, S. and Zeng, K. (2019). Biocontrol efficacy of Pichia membranaefaciens and Kloeckera apiculata against Monilinia fructicola and their ability to induce phenylpropanoid pathway in plum fruit. Biological Control, 129(29), 83-91. https://doi.org/10.1016/ j.biocontrol.2018.09.018

Zhang, J., Zeng, L., Sun, H., Zhang, J. and Chen, S. (2017). Using chitosan combined treatment with citric acid as edible coatings to delay postharvest ripening process and maintain tomato (Solanum lycopersicon Mill) quality. Journal of Food and Nutrition Research, 5(3), 144-150. 